\title{
Dynamics of methanogenesis, ruminal fermentation, and alfalfa degradation during adaptation to monensin supplementation in goats
}

\author{
Z. J. Li, ${ }^{*}$ H. Ren, ${ }^{*}$ S. M. Liu, † C. J. Cai, ${ }^{*}$ J. T. Han, ${ }^{*}$ F. Li, ${ }^{*} \ddagger$ and J. H. Yao*1 \\ ${ }^{*}$ College of Animal Science and Technology, Northwest A\&F University, Yangling, Shaanxi 712100, China \\ †UWA School of Agriculture and Environment, The University of Western Australia, Crawley, WA 6009, Australia \\ ‡College of Pastoral Agricultural Science and Technology, Lanzhou University, Lanzhou 730020, China
}

\section{ABSTRACT}

This study aimed to examine the temporal (hourly within a day and daily over the long term) effects of monensin on $\mathrm{CH}_{4}$ emissions, ruminal fermentation, and in situ alfalfa degradation in dairy goats during dietary monensin supplementation by controlling the confounding effects of feed intake and ambient temperature. Six ruminally cannulated dairy goats were used, and they were housed in environmental chambers and fed a restricted amount of ration throughout the experiment. The experiment included a baseline period of $20 \mathrm{~d}$ followed by a treatment period of $55 \mathrm{~d}$ with 32 mg of monensin/d. During the whole experiment, $\mathrm{CH}_{4}$ production was measured every $5 \mathrm{~d}$, whereas fermentation characteristics and in situ alfalfa degradation were analyzed every $10 \mathrm{~d}$. The $\mathrm{CH}_{4}$-depressing effect of monensin was time dependent on the duration of treatment, highly effective at $\mathrm{d} 5$ but thereafter decreased gradually until d 55 even though $\mathrm{CH}_{4}$-suppressing effect still remained significant. The decreasing effects of monensin on ruminal acetate proportion and acetate to propionate ratio also faded over days of treatment, and the acetate proportion returned up to the pre-supplementation level on d 50. Monensin supplementation elevated ruminal propionate proportion and decreased the effective ruminal degradability of alfalfa NDF, but both measurements tended to recover over time. The postprandial increase rate of hourly $\mathrm{CH}_{4}$ emissions was reduced, whereas that of propionate proportion was enhanced by monensin supplementation. However, the postprandial responses to monensin in $\mathrm{CH}_{4}$ emission rates, ruminal VFA profiles, and in situ degradation kinetics declined with both hours after feeding and days of treatment. Our results suggest that the $\mathrm{CH}_{4^{-}}$ suppressing effect of monensin supplementation in goats was attributed to reductions in both ruminal feed

Received May 30, 2017.

Accepted October 23, 2017

${ }^{1}$ Corresponding author: yaojunhu2004@sohu.com degradation and acetate to propionate ratio, but those reductions faded with time, hours after feeding, and days of treatment.

Key words: goat, methane emission, monensin, ruminal fermentation and degradation

\section{INTRODUCTION}

Ruminant production is confronted with massive challenges in animal health and productivity. Ruminal acidosis is commonly observed in ruminants when they are fed grain-based diets to increase production (Russell and Rychlik, 2001). Negative energy balance and subclinical ketosis are inherent to ruminants during the transition period and early lactation (Drackley, 1999). Additionally, ruminal $\mathrm{CH}_{4}$ emission contributes to global greenhouse gas emissions and represents an energy loss for the host animal (Johnson and Johnson, 1995; Hristov et al., 2013). As demonstrated by Shabat et al. (2016), inefficient cows produced less propionate but more $\mathrm{CH}_{4}$ in the rumen than their efficient peers. Monensin, as an ionophore, has been used in ruminant production to alleviate the above problems and improve animal's energy efficiency (McGuffey et al., 2001; Duffield et al., 2008a, 2008b, 2012; Patra et al., 2017).

However, the persistence of monensin effects remains controversial, especially its $\mathrm{CH}_{4}$-depressing effects (Sauer et al., 1998; Guan, 2006; Odongo et al., 2007; Appuhamy et al., 2013). For example, Guan (2006) reported that the $\mathrm{CH}_{4}$-depressing effect of monensin was short lived in cattle, whereas it was long lived in the study of Odongo et al. (2007). The animal's feed intake may interfere with the evaluation of monensin effects as discrepancies in its $\mathrm{CH}_{4}$-suppressing effects were found between measurements per day and per unit feed intake (Odongo et al., 2007). Additionally, it is well documented that ambient temperature can also influence $\mathrm{CH}_{4}$ production (Salles et al., 2008; Bernier et al., 2012) by affecting animal's DMI and nutrient degradation (Kennedy and Milligan, 1978; von Keyserlingk and Mathison, 1993). However, the ambient temperature fluctuates in long-term studies, such as in 
the study of Guan (2006) where ambient temperature varied between -28.6 to $6.7^{\circ} \mathrm{C}$ over $16 \mathrm{wk}$.

Furthermore, to our knowledge, the effects of monensin on postprandial variations of $\mathrm{CH}_{4}$ emissions, ruminal VFA profiles, and in situ degradation kinetics over days of treatment have never been studied, limiting our understanding of the temporal responses of the ruminal ecosystem to monensin. The objective of the present study was to investigate how monensin affects $\mathrm{CH}_{4}$ production, ruminal fermentation, and in situ degradation of alfalfa hay during a long-term $(55 \mathrm{~d})$ treatment in dairy goats by controlling the confounding factors of feed intake and ambient temperature. The postprandial temporal effects of monensin on the above measurements were also examined hourly following feeding monensin.

\section{MATERIALS AND METHODS}

All experimental procedures were approved by the Northwest A\&F University Animal Care and Use Committee.

\section{Animals, Diets, and Experimental Design}

Six nonlactating Xinong Saanen dairy goats, approximately 4 yr of age, with similar BW $(54 \pm 2.4$ $\mathrm{kg}$ ), body condition (health), and feed intake behavior (good appetite) were used in this study. The goats were fitted with permanent ruminal cannulas and had never been exposed to monensin before the experiment. A TMR (Table 1) was formulated to meet the nutrient requirements for maintenance (NY/T 816-2004; Ministry of Agriculture of China, 2004). The goats were fed the same amount of TMR equivalent to $330 \mathrm{~g}$ of alfalfa hay, $281 \mathrm{~g}$ of corn silage, and $408 \mathrm{~g}$ of concentrate twice daily in 2 equal meals at 0800 and $1800 \mathrm{~h}$. The goats had free access to drinking water. The amounts of feeds refused, if any, were recorded daily.

The goats were first allowed to adapt to the environmental chambers and the TMR diet for 2 mo. Then, feeding experiment lasted for $75 \mathrm{~d}$, including a baseline period (without monensin) for $20 \mathrm{~d}$ and a treatment period of $55 \mathrm{~d}$ (d 1-55), during which $16 \mathrm{mg}$ of monensin $(20 \%$ monensin in the Rumensin premix, Elanco Animal Health, Greenfield, IN) was top dressed onto a small amount of corn silage that was offered to each goat before each feeding.

Five indoor environmental chambers $(7.4 \mathrm{~m} \times 4.2$ $\mathrm{m} \times 2.7 \mathrm{~m}$ ) were used in this study, with 2 chambers serving as adaptation chambers to allow the goats to adapt to the chamber environments and 3 chambers as gas measurement chambers. The goats were randomly divided equally into 2 groups, and the 3 goats of each group were housed in 1 of the 2 adaptation chambers. The 3 goats were separated by placing each in a metabolic cage $(1.5 \mathrm{~m} \times 1.0 \mathrm{~m} \times 1.5 \mathrm{~m})$. The adaptation chambers were kept open to the indoor atmosphere to ensure adequate air exchange. The feeding experiment started in a staggered manner for the 2 groups of goats with a 3-d interval so that gas emissions from each group of the 3 goats could be measured individually using the 3 gas measurement chambers. The temperature inside the chambers was maintained between 6 and $14^{\circ} \mathrm{C}$, and the goats were subjected to a diurnal cycle of $14 \mathrm{~h}$ of light and $10 \mathrm{~h}$ of darkness throughout the experiment. The goats were housed in the adaptation chambers and were moved to the gas measurement chambers only when their gas emissions were measured.

\section{Measuring Methane Emissions and DMI}

During both the baseline and the monensin treatment periods, $\mathrm{CH}_{4}$ and $\mathrm{CO}_{2}$ emissions from each goat were measured every $5 \mathrm{~d}$ using the approach of Goopy et al. (2011) with minor modifications. By this approach, gas emission from each goat was measured by determining the gas accumulation inside each airtight chamber with a fixed volume over a period of time. The system-alarm concentration of $\mathrm{CO}_{2}$ was set at 2,000 ppm, much lower than the threshold level of 10,000 ppm for animals (Weissman et al., 1984; Hellwing et al., 2012). The internal volume of each chamber was $83.9 \mathrm{~m}^{3}$, which is about 137 times larger than that $\left(0.613 \mathrm{~m}^{3}\right)$ used by Goopy et al. (2011), allowing for an extended duration of gas measurement in the closed chambers.

Table 1. Ingredients and chemical composition of the experimental diet

\begin{tabular}{lc}
\hline Item & $\%(\mathrm{DM})$ \\
\hline Ingredient & \\
Corn silage & 26.8 \\
Alfalfa hay & 33.3 \\
Crushed corn & 28.0 \\
Soybean meal & 10.8 \\
Vitamin-mineral premix $^{1}$ & 0.1 \\
$\mathrm{CaHPO}_{4}$ & 0.3 \\
$\mathrm{CaCO}_{3}$ & 0.3 \\
Salt & 0.4 \\
Chemical composition & 49.3 \\
DM & 93.8 \\
OM & 14.7 \\
CP & 33.9 \\
NDF & 23.9 \\
ADF & \\
\hline
\end{tabular}

${ }^{1}$ Vitamin-mineral premix (per kg): $600 \mathrm{mg}$ of Mn, $950 \mathrm{mg}$ of Zn, 430 $\mathrm{mg}$ of $\mathrm{Fe}, 650 \mathrm{mg}$ of $\mathrm{Cu}, 30 \mathrm{mg}$ of Se, $45 \mathrm{mg}$ of I, $20 \mathrm{mg}$ of Co, $450 \mathrm{mg}$ of nicotinic acid, $800 \mathrm{mg}$ of vitamin E, 45,000 IU of vitamin D, and $120,000 \mathrm{IU}$ of vitamin A. 
Briefly, a total of $24 \mathrm{~h}$ of gas emissions from each goat was measured in 2 consecutive days over 3 separate periods: 0000 to $0800 \mathrm{~h}$ and 1800 to $2400 \mathrm{~h}$ on the first day and then 0800 to $1800 \mathrm{~h}$ on the second day. At the end of each period, the chamber doors were kept open to allow fresh air in, and the chamber was cleaned before the next period. During the gas measurement periods, the air inside each chamber was mixed for 30 s every $10 \mathrm{~min}$ by 4 draft fans, and continuously and constantly pumped at a rate of $2 \mathrm{~L} / \mathrm{min}$ to the $\mathrm{CH}_{4}$ analyzer (model 55i, Thermo Fisher Scientific Inc., Waltham, MA) and $\mathrm{CO}_{2}$ analyzer (BAIF-Maihak Analytical Instrument Co. Ltd., Beijing, China). The concentrations of $\mathrm{CH}_{4}$ and $\mathrm{CO}_{2}$ in the 3 chambers were analyzed sequentially, 5 min for each chamber every 15 min (4 times per $\mathrm{h}$ for each chamber).

The hourly and daily $\mathrm{CH}_{4}$ emissions were calculated as follows:

$$
\begin{gathered}
\mathrm{CH}_{4} \text { emission }(\mathrm{L} / \mathrm{h} \text { or } \mathrm{L} / \mathrm{d})=\Sigma\left[\left(\mathrm{C}_{\mathrm{i}}-\mathrm{C}_{\mathrm{i}-1}\right)\right. \\
\left.\times \mathrm{V}_{\mathrm{c}}+\mathrm{V}_{\mathrm{f}} \times\left(\mathrm{C}_{\mathrm{i}}-\mathrm{C}_{0}\right)\right] / 1,000,
\end{gathered}
$$

where $\left(\mathrm{C}_{\mathrm{i}}-\mathrm{C}_{\mathrm{i}-1}\right)=$ the difference of $\mathrm{CH}_{4}$ concentration (ppm) in every $15 \mathrm{~min} ; \mathrm{C}_{0}=$ the initial $\mathrm{CH}_{4}$ concentration $(\mathrm{ppm})$ of each period; $\mathrm{V}_{\mathrm{c}}=$ the chamber volume $\left(83.9 \mathrm{~m}^{3}\right)$; and $\mathrm{V}_{\mathrm{f}}=$ the gas volume pumped from each chamber over each 15 -min measurement $\left(0.03 \mathrm{~m}^{3}\right)$.

Feed and individual ort samples were collected on the days of gas measurement, dried at $55^{\circ} \mathrm{C}$ for 72 $\mathrm{h}$, and then ground through a $1-\mathrm{mm}$ screen. Those samples were analyzed to determine the content of DM (method 934.01, AOAC International, 2005), ash (method 942.05, AOAC International, 2005), and CP (method 954.01, AOAC International, 2005). The NDF and ADF contents were determined according to the method of Van Soest et al. (1991) using sodium sulfite and a heat-stable $\alpha$-amylase (Ankom A200I fiber analyzer, Ankom Technology, Macedon, NY).

\section{Collection and Analysis of Ruminal Fluid}

During the baseline and the monensin treatment periods, rumen samples of each goat were collected from the anterior ventral sac of the rumen at $0,1,2,4,6$, and $8 \mathrm{~h}$ after the morning feeding, and the samples were collected every $10 \mathrm{~d}$ on the day after every other gas measurement. Ruminal $\mathrm{pH}$ was measured immediately after sampling using a $\mathrm{pH}$ meter. Then, the ruminal samples were strained through 4 layers of cheesecloth. A subsample of $5 \mathrm{~mL}$ of ruminal fluid was mixed with $1 \mathrm{~mL}$ of $25 \%$ metaphosphoric acid and stored at $-40^{\circ} \mathrm{C}$ until it was analyzed for VFA.
Ruminal VFA concentrations were analyzed by GC (Agilent Technologies 7820A GC system, Santa Clara, CA) using a $30 \mathrm{~m} \times 0.25 \mathrm{~mm} \times 0.33 \mu \mathrm{m}$ fused silica column (AE-FFAP, Atech Technologies Co. Ltd., Shanghai, China) after removing the solid particle and protein according to the procedures of $\mathrm{Li}$ et al. (2014).

\section{In Situ Alfalfa Hay Degradation}

In situ alfalfa hay degradation was determined using nylon bags as recommended by NRC (2001) every $10 \mathrm{~d}$ in the baseline period and the first $20 \mathrm{~d}$ of the monensin treatment period, and then every $15 \mathrm{~d}$. Briefly, alfalfa hay was milled through a $2-\mathrm{mm}$ screen. About $2.5 \mathrm{~g}$ (DM) of alfalfa hay were each placed in individual nylon bags $(10 \times 8 \mathrm{~cm})$ with a pore size of $50 \mu \mathrm{m}$, resulting in a ratio of the sample weight to the bag surface area of $15 \mathrm{mg} / \mathrm{cm}^{2}$. The bags were placed inside the goat rumen through the cannula before the morning feeding. Two nylon bags were each retrieved after 2, 4, 8, 16, 24, 48 , and $72 \mathrm{~h}$ of incubation. The retrieved nylon bags were rinsed in tap water and then dried at $55^{\circ} \mathrm{C}$ for 72 $\mathrm{h}$. The alfalfa residues in each bags were analyzed for DM and NDF contents. Degradation parameters and effective ruminal degradability (ERD) were calculated using the nonlinear regression procedure of SAS 9.2 (SAS Inst. Inc., Cary, NC) according to the following model (Ørskov and McDonald, 1979):

$$
\mathrm{Y}_{t}=a+b \times\left(1-\mathrm{e}^{-k t}\right),
$$

in which $\mathrm{Y}_{t}=$ disappearance proportion at time $t, a$ $=$ rapidly degradable fraction; $b=$ slowly degradable fraction; $k=$ constant rate of degradation of fraction $b$; and $t=$ time of incubation (h).

$$
\mathrm{ERD}=a+b \times k /(k+k p),
$$

in which $a, b$, and $k$ are the degradation parameters as described above and $k p$ is passage rate of roughage $\left(0.04 \mathrm{~h}^{-1}\right.$, Offner et al., 2003).

\section{Statistical Analysis}

The measurements during the baseline period were averaged for each goat as the pre-supplementation values. The $\mathrm{CH}_{4}$ emissions, ruminal fermentation parameters, and in situ degradation were analyzed as a 1-way repeated measures ANOVA using the PROC MIXED program in SAS with animal as a random effect. Days of the whole experimental period and days of the monensin treatment period were treated as repeated fac- 
tors to identify statistically significant fluctuations over time.

Hourly $\mathrm{CH}_{4}$ emissions during the first $11 \mathrm{~h}$ [from preprandial $1 \mathrm{~h}$ (the $0 \mathrm{~h}$ data) to the postprandial 10 $\mathrm{h}$ ] were calculated for each goat by averaging that of the morning and afternoon feeding. And the 2 measurements of postprandial hourly $\mathrm{CH}_{4}$ emissions in every $10 \mathrm{~d}$ were averaged to match the timelines of other measurements. The postprandial hourly variations in $\mathrm{CH}_{4}$ emissions and ruminal VFA profiles over days of the entire experimental period were analyzed using 2-way ANOVA for repeated measures using the PROC MIXED program with day and hour as repeated factors and animal as a random effect; interaction of day $x$ hour was also examined.

Student $t$-test for paired samples was performed to test differences among days of the experimental period and differences between the baseline and the monensin treatment periods. Statistical significance was declared at $P<0.05$, whereas a trend was declared at $0.05 \leq P$ $<0.10$.

\section{RESULTS}

\section{Effects of Monensin on DMI and Methane Production}

On average, greater than $97 \%$ of the diets offered daily to each goat was consumed, and no difference was observed in DMI between the baseline and the monensin treatment periods $(P=0.328)$ or over days of the experiment $(P=0.782$; Table 2$)$. The monensin supplementation decreased the $\mathrm{CH}_{4}$ emissions $(P=0.001)$ in goats expressed either as liters per day or as liters per day per kilogram of DMI. However, the $\mathrm{CH}_{4}$-depressing effect decreased gradually over days of the monensin treatment $(P<0.001)$. Compared with the baseline period, the daily $\mathrm{CH}_{4}$ production was decreased effectively (by 20.3 and $18.4 \%$ based on $\mathrm{L} / \mathrm{d}$ and L/ $\mathrm{kg} \mathrm{DMI}$, respectively) at $\mathrm{d} 5$, but the $\mathrm{CH}_{4}$-depressing effect decreased gradually during the monensin treatment period, and the $\mathrm{CH}_{4}$ production was only decreased by 5.3 and $4.5 \%$, when expressed as liters per day and liters per kilogram of DMI, respectively, at d 55 .

The postprandial temporal variations of $\mathrm{CH}_{4}$ emission rates $(\mathrm{L} / \mathrm{h})$ after feeding monensin are presented in Figure 1. Hourly $\mathrm{CH}_{4}$ emissions were significantly affected by days of the experiment $(P<0.001)$ and hours after feeding $(P<0.001)$, and an interaction between day and hour was also observed $(P<0.001)$. Hourly $\mathrm{CH}_{4}$ emissions peaked at the first postprandial hour during the baseline period, whereas during the monensin treatment period, it peaked at the fourth postprandial hour during d 5 to 10 , and thereafter, it peaked sooner during d 15 to 50, at the second postprandial hour.

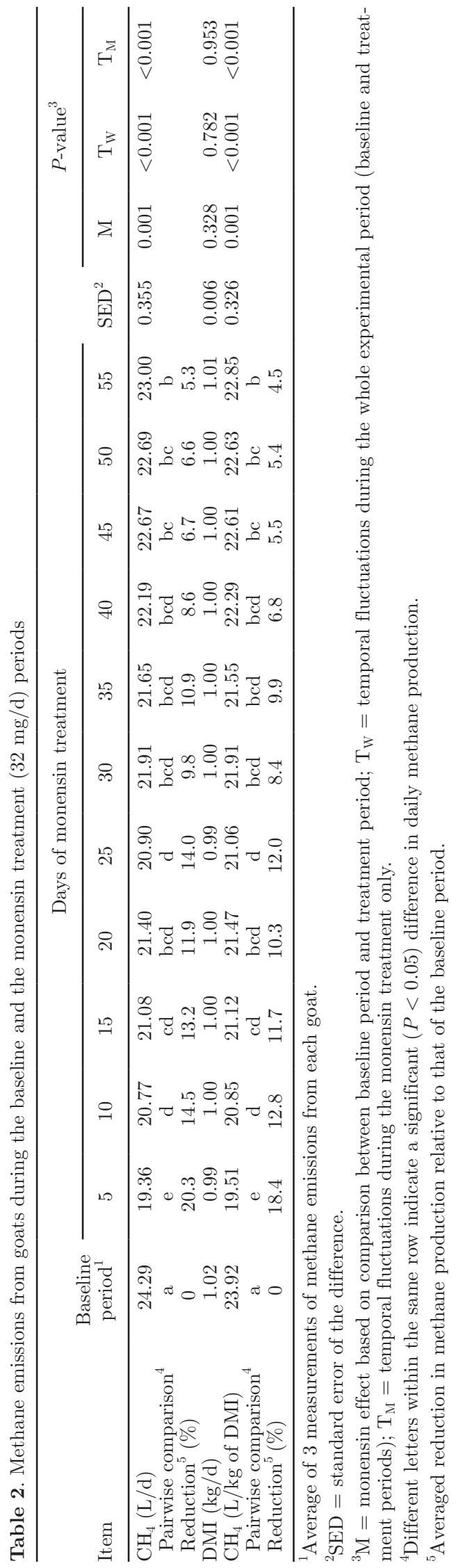

Journal of Dairy Science Vol. 101 No. 2, 2018 
Moreover, the postprandial hourly $\mathrm{CH}_{4}$ emissions were also reduced by monensin, but the magnitude of the reduction declined with hours after feeding and with days of treatment.

\section{Effects of Monensin on Ruminal Fermentation Characteristics}

The effects of monensin supplementation on rumen fermentation parameters during the baseline and the monensin treatment periods are summarized in Table 3 . The ruminal $\mathrm{pH}$ tended to decrease over the course of the entire experiment $(P=0.059)$, but it did not differ between the baseline and the monensin treatment periods $(P=0.115)$ or over the course of the monensin treatment period $(P=0.841)$. The monensin supplementation changed the VFA profiles in a timedependent manner except those of butyrate and valerate. Ruminal total VFA concentration was reduced $(P=0.005)$ by monensin, and the magnitude of the decrease fluctuated with days of treatment $(P<0.001)$. Ruminal acetate molar proportion $(P=0.033)$ and the ratio of acetate to propionate $(\mathbf{A}: \mathbf{P}, P=0.003)$ were lowered by monensin, but both measurements increased

\begin{tabular}{cccccccccccc}
\hline daylhour & $0 \mathrm{~h}$ & $1 \mathrm{~h}$ & $2 \mathrm{~h}$ & $3 \mathrm{~h}$ & $4 \mathrm{~h}$ & $5 \mathrm{~h}$ & $6 \mathrm{~h}$ & $7 \mathrm{~h}$ & $8 \mathrm{~h}$ & $9 \mathrm{~h}$ & $10 \mathrm{~h}$ \\
\hline Baseline & $\mathrm{a}$ & $\mathrm{a}$ & $\mathrm{a}$ & $\mathrm{a}$ & $\mathrm{a}$ & $\mathrm{a}$ & $\mathrm{a}$ & $\mathrm{a}$ & $\mathrm{a}$ & $\mathrm{a}$ & $\mathrm{a}$ \\
$\mathrm{d} 5-10$ & $\mathrm{bc}$ & $\mathrm{c}$ & $\mathrm{d}$ & $\mathrm{d}$ & $\mathrm{b}$ & $\mathrm{b}$ & $\mathrm{d}$ & $\mathrm{c}$ & $\mathrm{b}$ & $\mathrm{b}$ & $\mathrm{b}$ \\
$\mathrm{d} 15-20$ & $\mathrm{bc}$ & $\mathrm{c}$ & $\mathrm{c}$ & $\mathrm{cd}$ & $\mathrm{b}$ & $\mathrm{ab}$ & $\mathrm{bc}$ & $\mathrm{c}$ & $\mathrm{b}$ & $\mathrm{ab}$ & $\mathrm{b}$ \\
$\mathrm{d} 25-30$ & $\mathrm{c}$ & $\mathrm{c}$ & $\mathrm{bc}$ & $\mathrm{c}$ & $\mathrm{b}$ & $\mathrm{b}$ & $\mathrm{c}$ & $\mathrm{bc}$ & $\mathrm{ab}$ & $\mathrm{ab}$ & $\mathrm{b}$ \\
$\mathrm{d} 35-40$ & $\mathrm{~b}$ & $\mathrm{c}$ & $\mathrm{b}$ & $\mathrm{abc}$ & $\mathrm{ab}$ & $\mathrm{ab}$ & $\mathrm{c}$ & $\mathrm{ab}$ & $\mathrm{b}$ & $\mathrm{ab}$ & $\mathrm{ab}$ \\
$\mathrm{d} 45-50$ & $\mathrm{ab}$ & $\mathrm{b}$ & $\mathrm{ab}$ & $\mathrm{bc}$ & $\mathrm{ab}$ & $\mathrm{ab}$ & $\mathrm{b}$ & $\mathrm{ab}$ & $\mathrm{ab}$ & $\mathrm{ab}$ & $\mathrm{ab}$ \\
\hline
\end{tabular}

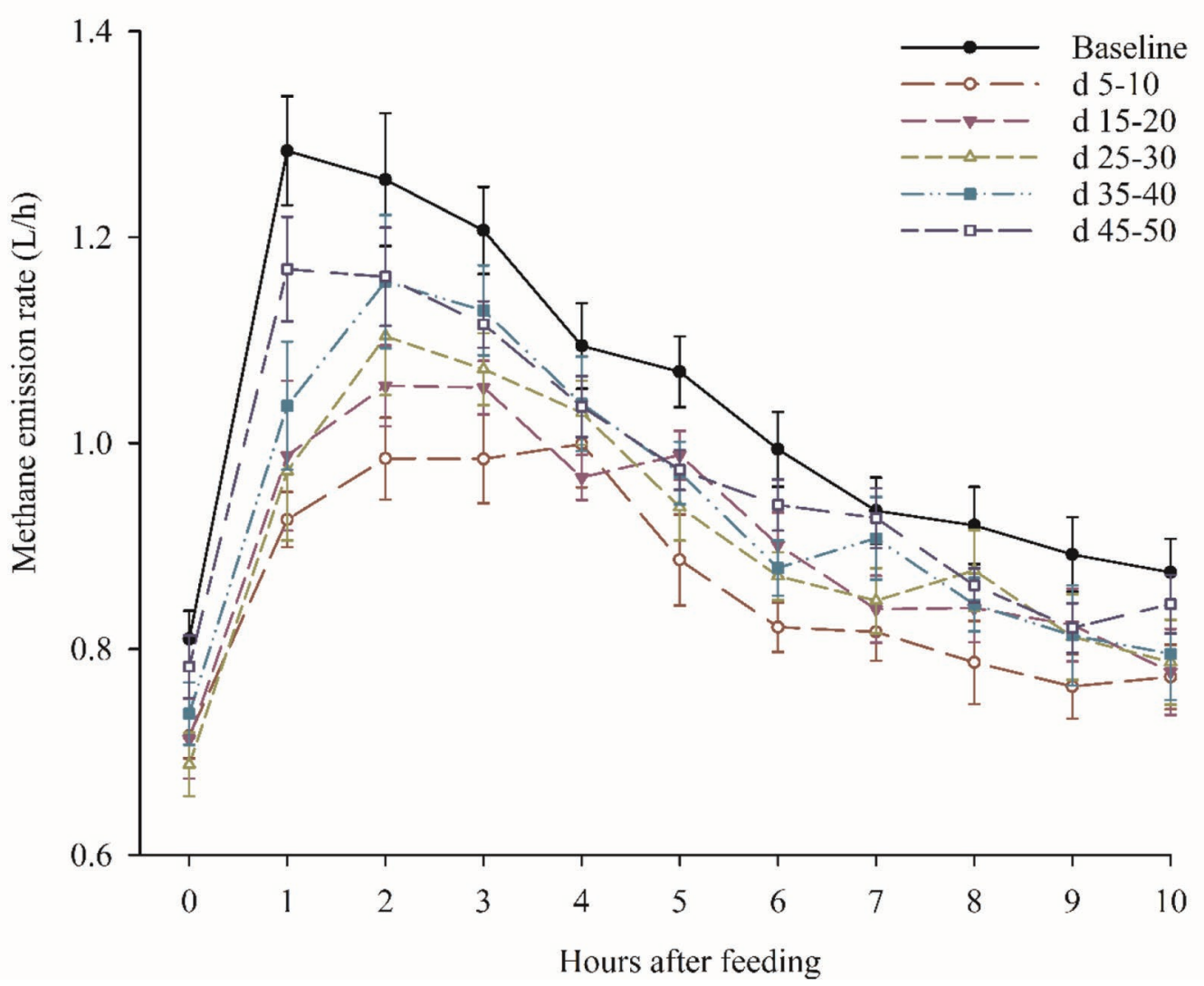

Figure 1. Postprandial temporal variations of $\mathrm{CH}_{4}$ emission rates $(\mathrm{L} / \mathrm{h})$ in the goats. The hourly $\mathrm{CH}_{4}$ emissions from preprandial $1 \mathrm{~h}(0 \mathrm{~h})$ to postprandial $10 \mathrm{~h}$ were calculated for each goat by averaging the $\mathrm{CH}_{4}$ production of the morning and afternoon feeding. Error bars represent SEM $(\mathrm{n}=6)$. Different lowercase letters $(\mathrm{a}-\mathrm{d})$ within the same column in the table indicate significant difference $(P<0.05)$. All the statistical significances of day, hour, and their interaction were less than 0.001. Color version available online. 
gradually with days of treatment $(P<0.05)$, and the acetate proportion was restored up to the pre-supplementation level on $\mathrm{d} 50$. The increasing effect $(P=$ 0.001 ) of monensin on ruminal propionate proportion tended to decline over days of treatment $(P=0.091)$.

The postprandial responses to monensin in ruminal acetate molar proportion declined with both hours after feeding $(P=0.003)$ and days of treatment $(P<$ $0.001)$, and an day $\times$ hour interaction $(P=0.001)$ was also observed (Figure 2A). Compared with that of the baseline period, acetate molar proportion was lowered by monensin from 0 to $4 \mathrm{~h}$ after morning feeding, but thereafter it recovered to the baseline level at sixth and eighth postprandial hour on d 10 and 20 (Figure $2 \mathrm{~A}$ ). The acetate inhibition also gradually diminished with days of treatment, and by d 50, acetate molar proportion recovered to the baseline value at all the sampling time points. The propionate-promoting effect of monensin also decreased with both hours after feeding $(P<0.001)$ and days of treatment $(P<0.001)$, and no difference in propionate molar proportion was seen between the eighth postprandial hour on d 50 and the baseline period (Figure 2B).

\section{Effect of Monensin on In Situ Alfalfa Hay Degradation}

The in situ degradation kinetic parameters and ERD of alfalfa hay in goats are presented in Table 4. The ERD of alfalfa hay DM and NDF $(P<0.05)$ were reduced by monensin, and the ERD of alfalfa hay NDF tended to increase over days of monensin treatment $(P$ $=0.079)$. The degradations of rapidly degradable fractions of alfalfa hay DM and NDF were decreased $(P$ $<0.05)$ by monensin but in a time-dependent manner $(P<0.01)$, as they declined from per supplementation to $\mathrm{d} 10$ and thereafter increased gradually up to the baseline value on $\mathrm{d} 50$. However, the degradation of slowly degradable fraction of NDF tended to be higher during the monensin treatment period than in baseline period $(P=0.093)$.

\section{DISCUSSION}

\section{Relationships Among Ambient Temperature, DMI, and Rumen Fermentation}

In the current study, fluctuations in DMI during the entire experiment period were minimized by controlling the amount of TMR offered and maintaining a relatively stable temperature $\left(6\right.$ to $\left.14^{\circ} \mathrm{C}\right)$ in the chambers. Temperature is one factor that can affect DMI, with low temperature increasing DMI but decreasing feed degradation (Kennedy and Milligan, 1978; von Keyserlingk 
A

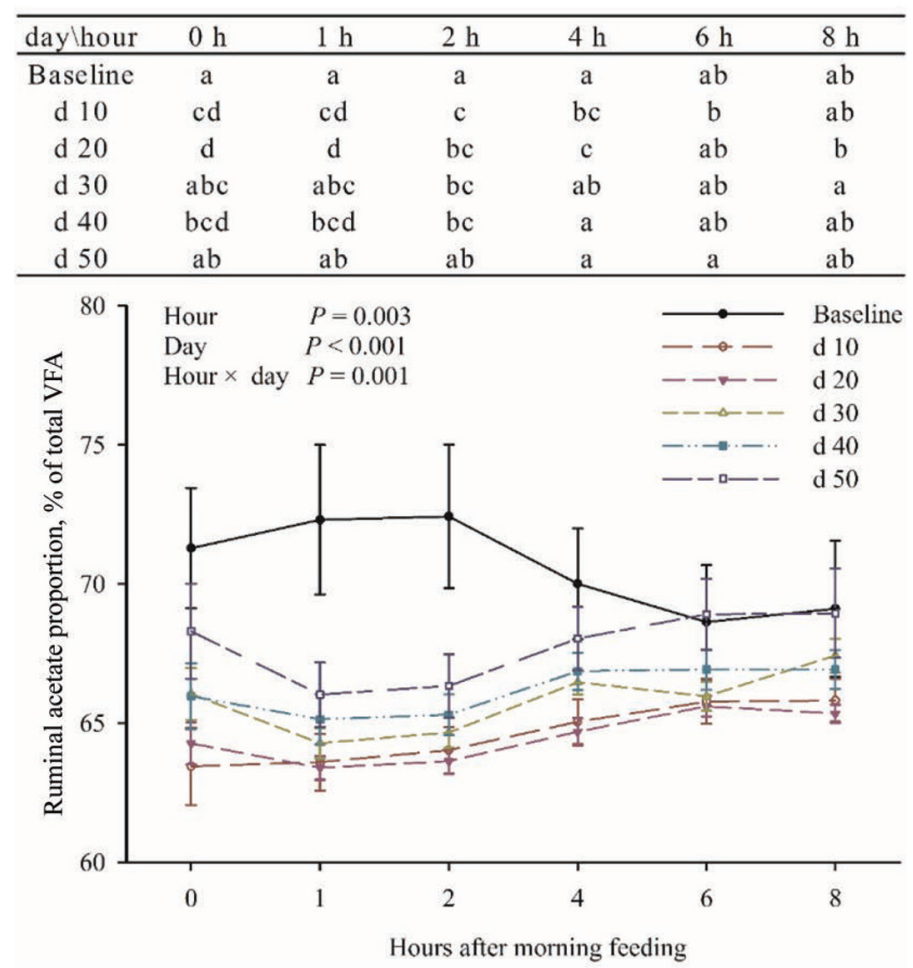

B

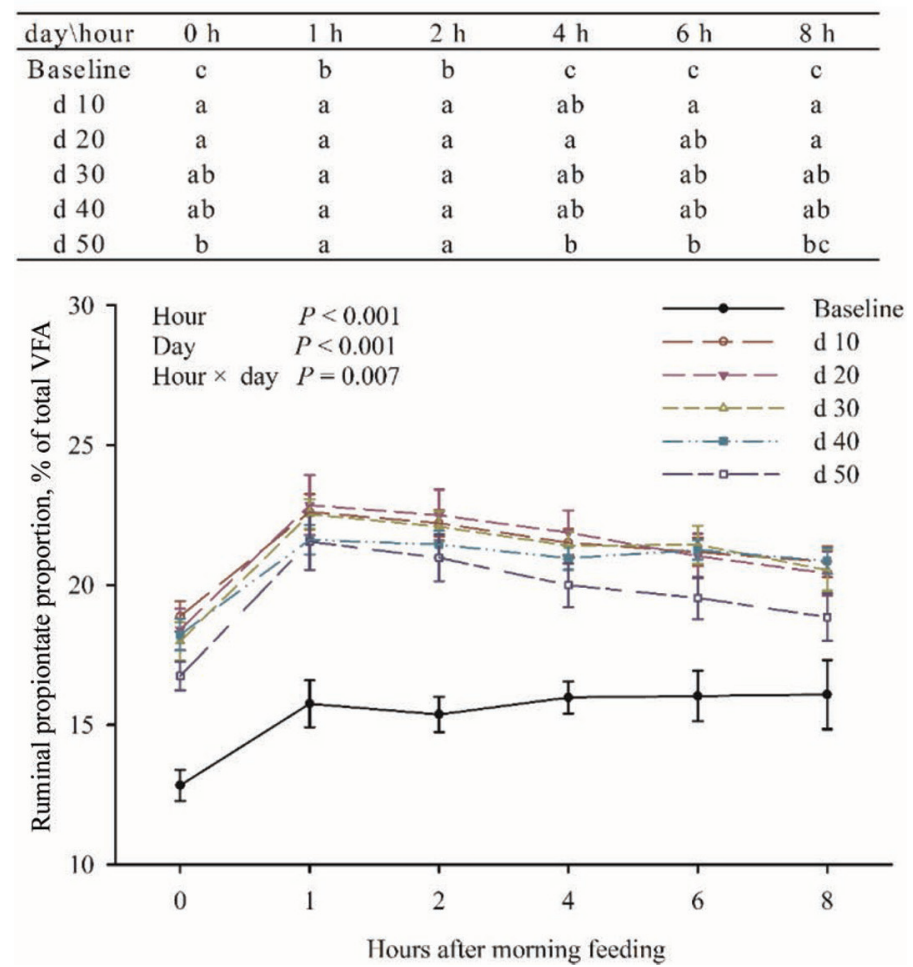

Figure 2. Postprandial variations of molar proportions of ruminal acetate (A) and propionate (B) in the goats. Error bars represent SEM $(\mathrm{n}=6)$. The $P$-value showed the effects of day, hour, and their interaction determined using 2-way ANOVA analysis for repeated measures. Different lowercase letters within the same column in the table indicate a significant difference $(P<0.05)$. Color version available online. 
and Mathison, 1993; Salles et al., 2008) by increasing passage rate and thus shortening the mean retention time (Kennedy and Milligan, 1978; Kadzere et al., 2002). Mathematically, DMI can influence the production of end products in rumen fermentation, and this is demonstrated by $\mathrm{CH}_{4}$ emissions being proportional to DMI (Boadi and Wittenberg, 2002; Grainger et al., 2007). Therefore, temperature can also affect rumen fermentation and $\mathrm{CH}_{4}$ emissions indirectly (Salles et al., 2008; Bernier et al., 2012). Although several studies have shown that monensin has no effect on DMI (Odongo et al., 2007; Grainger et al., 2008; Waghorn et al., 2008), 2 meta-analyses (Duffield et al., 2008a; Appuhamy et al., 2013) revealed a 2.3 to $2.6 \%$ decrease in DMI in dairy cows fed monensin. Odongo et al. (2007) observed a $6.5 \%$ reduction in $\mathrm{CH}_{4}$ emissions $(\mathrm{g} / \mathrm{d})$ by cows fed $24 \mathrm{mg}$ of monensin $/ \mathrm{kg}$ of DM, and the $\mathrm{CH}_{4}$ depression was sustained for 6 mo; however, when expressed as liters of $\mathrm{CH}_{4}$ per kilogram of NDF intake, the monensin treatment had no effect. Discrepancies in $\mathrm{CH}_{4}$-depressing effects of monensin were also reported between $\mathrm{CH}_{4}$ production per day and per unit of feed intake in the same study (Guan, 2006; da Fonseca et al., 2016). Apparently, controlling confounding factors, such as temperature and DMI, is necessary to assess the effect of monensin and to advance the mechanistic understanding of monensin on rumen fermentation and $\mathrm{CH}_{4}$ emissions. By controlling these 2 confounding factors, we showed a consistent $\mathrm{CH}_{4}$-depressing effect when $\mathrm{CH}_{4}$ emissions were expressed as liters per day or as liters per kilogram of DMI.

\section{Effects of Monensin on Daily Methane Production During Adaptation to Monensin}

Monensin still exhibited significant inhibition of $\mathrm{CH}_{4}$ production at the end of the monensin treatment $(\mathrm{d}$ 55), but its long-term efficacy is probably small as its $\mathrm{CH}_{4}$-depressing efficacy continued to fade over time, even during the latter days of the treatment. Johnson and Johnson (1995) and Guan (2006) showed that the $\mathrm{CH}_{4}$-depressing effects of monensin were short lived in cattle and lasted for less than $30 \mathrm{~d}$. The longer efficacy observed in the present study is probably attributable to the experimental design of repeated measures and the high sensitivity of the Student $t$-test for paired samples (self-comparison) because one-way ANOVA test of the $\mathrm{CH}_{4}$ data showed no difference in $\mathrm{CH}_{4}$ production between the baseline period and the latter days (d 35 to 55) of the monensin treatment (data not shown). These results corroborate the development of resistance to monensin by ruminal microbes (Johnson and Johnson, 1995). Sauer et al. (1998) found that the ruminal microbiota in cows could become adapted to monensin after the first treatment and did not respond to repeated monensin supplementation. Guan (2006) observed a reduction of ruminal protozoal populations in cow receiving monensin, but that reduction appeared to be a short-term effect, with a total recovery after 4 to 6 wk of the treatment. Several studies also documented resistance of gram-positive bacteria to monensin (Newbold et al., 1993; Ravva et al., 2013; Kim et al., 2014b). No alteration in the abundance or diversity of metha-

Table 4. In situ alfalfa hay degradation in the rumen of the goats during the baseline period and the monensin supplementation (32 mg/d) period

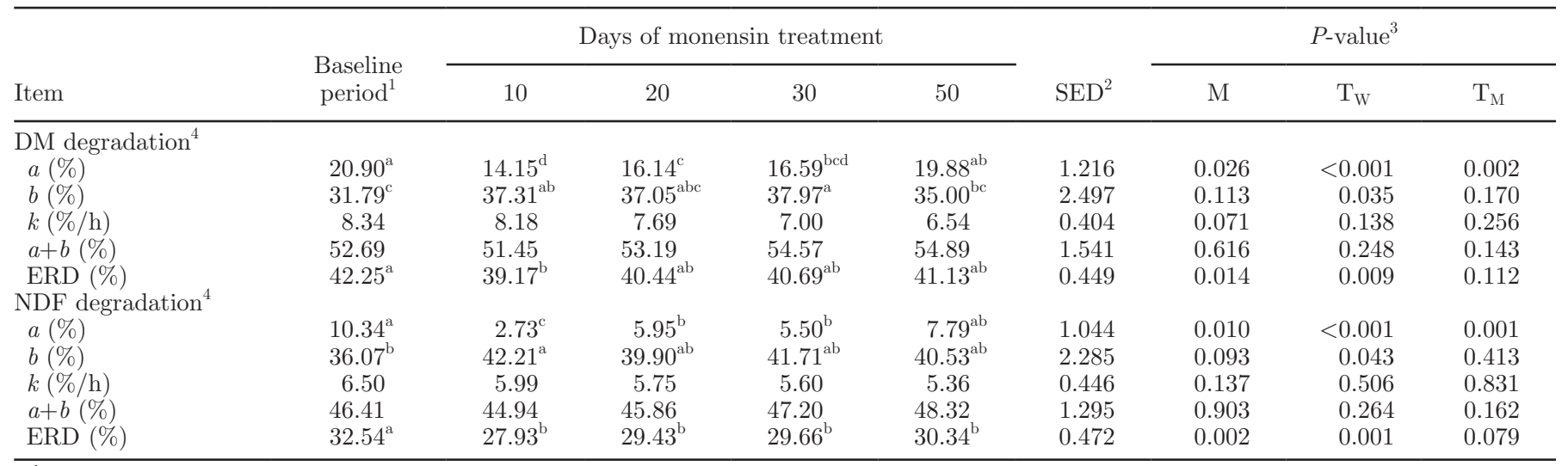

\footnotetext{
${ }^{\mathrm{a}-\mathrm{d}}$ Values with different superscripts within the same row differ significantly $(P<0.05)$.

${ }^{1}$ Average of 2 measurements for each goat.

${ }^{2} \mathrm{SED}=$ standard error of the differences.

${ }^{3} \mathrm{M}=$ monensin effects based on comparison between the baseline and the monensin treatment periods; $\mathrm{T}_{\mathrm{W}}=$ temporal fluctuations during the whole experimental period (baseline and treatment periods); $\mathrm{T}_{\mathrm{M}}=$ temporal fluctuations during the monensin treatment only.

${ }^{4} a=$ rapidly degradable fraction; $b=$ slowly degradable fraction; $k=$ constant rate of degradation of fraction b; $a+b=$ potential extent of degradation; effective ruminal degradability $(\mathrm{ERD})=a+b \times k /(k+k p)$, where $k p$ is the passage rate of roughage $\left(0.04 \mathrm{~h}^{-1}\right.$, Offner et al., 2003$)$.
} 
nogens was observed upon monensin supplementation (Chen and Wolin, 1979; Hook et al., 2009; Scharen et al., 2017), suggesting that methanogens are resistant to monensin. Therefore, the $\mathrm{CH}_{4}$-depressing effects of monensin are most likely attributed to its ability to lower the availability of methanogenic substrates, especially $\mathrm{H}_{2}$, rather than to direct inhibition to methanogens (McGuffey et al., 2001). Based on the pathways of carbohydrate fermentation, the $\mathrm{H}_{2}$ available for methanogenesis depends primarily on the amount of dietary carbohydrate fermented and the ruminal VFA profiles. Given the same DMI between the baseline and the monensin treatment periods in the current study, our results suggest that monensin inhibits $\mathrm{CH}_{4}$ production by lowering the rate of ruminal dietary degradation and shifting the ruminal VFA files to a lower A:P (Russell, 1998; Ungerfeld, 2015).

\section{Effects of Monensin on Ruminal VFA Profiles During Adaptation to Monensin}

Acetate production during rumen fermentation is accompanied by $\mathrm{H}_{2}$ production, whereas propionate production is accompanied with $\mathrm{H}_{2}$ consumption (Hegarty 1999; Janssen, 2010). Consistent with the findings of other studies, monensin decreased the ruminal A:P (Brown and Hogue, 1985; Tomkins et al., 2015; Wang et al., 2015) but had no effect on the proportion of butyrate or valerate (Gehman et al., 2008; Tomkins et al., 2015; Vendramini et al., 2015). These shifts in VFA profiles could be driven by inhibition of grampositive bacteria and protozoa (Russell, 1987; Russell and Houlihan, 2003; Kim et al., 2014a), both of which produce acetate and $\mathrm{H}_{2}$ as fermentation end products (McGuffey et al., 2001; Tedeschi et al., 2003). The shift from acetate to propionate reduces the $\mathrm{H}_{2}$ available for methanogenesis (Russell, 1998; Ungerfeld, 2015), explaining, at least partially, the monensin inhibition to $\mathrm{CH}_{4}$ production seen in this study.

The time-dependent effect of monensin on ruminal propionate proportion $(P=0.091)$ was weaker than that on $\mathrm{CH}_{4}$ production $(P<0.001)$ during the monensin treatment. The relatively persistent shifts in VFA profiles by monensin are in general accordance with previous observations (Rogers et al., 1997; Guan, 2006). Guan (2006) reported that the monensin-induced reduction of ruminal A:P was maintained for at least 12 weeks, whereas that of $\mathrm{CH}_{4}$ emissions was maintained up to $4 \mathrm{wk}$. The increased propionate production by monensin cannot only decrease $\mathrm{H}_{2}$ availability for methanogenesis but also increase the precursor for gluconeogenesis in animals, which would improve animal's energy efficiency (Shabat et al., 2016). A previous meta-analysis by Duffield et al. (2012) revealed that monensin supplementation improved feed efficiency in cattle by $1.3 \%$. Because monensin can provide a persistent energetic advantage by enhancing propionate production, we agree with the assertion of Tedeschi et al. (2003) that monensin is effective to reduce $\mathrm{CH}_{4}$ emissions from ruminants, despite potential microbial adaptation, because it can decrease the $\mathrm{CH}_{4}$ output per kilogram of milk or meat.

The effects of monensin supplementation on total VFA concentration have been variable among previous studies (Salles et al., 2008; Khorrami et al., 2015; Lemos et al., 2016), which may be attributed to the duration of monensin treatment. In this long-term study, temporal variations in total VFA concentration were seen over the course of the monensin treatment $(P<0.001)$, which is in agreement with the results of Rogers et al. (1997). Although monensin reduced the total VFA concentration, no difference in ruminal $\mathrm{pH}$ was observed, which is consistent with previous observations (Fairfield et al., 2007; Khorrami et al., 2015; Tomkins et al., 2015; Mirzaei-Alamouti et al., 2016). The monensin-induced decrease in total VFA concentration might be probably too small to change the ruminal $\mathrm{pH}$.

\section{Effects of Monensin on ERD of Alfalfa Hay During Adaptation to Monensin}

Consistent with previous studies (Reveneau et al., 2012; Montano et al., 2015), monensin reduced ruminal digestion of OM and fiber. Such adverse effects of monensin on ruminal fiber degradation have been attributed to its inhibition of cellulolytic bacteria and protozoa in the rumen (Khorrami et al., 2015; Wang et al., 2015). As confirmed in the present study, the reduced DM digestibility corresponded with the decreased ruminal VFA concentration and $\mathrm{CH}_{4}$ production (Jentsch et al., 2007). However, monensin did not lower apparent total-tract digestibility in numerous previous studies (Gehman et al., 2008; Salles et al., 2008; Reveneau et al., 2012; Khorrami et al., 2015), probably because the reduced ruminal digestibility was compensated by increased postruminal digestion (Haimoud et al., 1995; Reveneau et al., 2012).

So far no studies in the literature have evaluated the dynamics of in situ feed degradation over days of the monensin treatment. In the present study, we showed that the inhibition of ERD of alfalfa hay by monensin became weak over the course of the monensin treatment period. The time-dependent patterns in ERD of alfalfa NDF mirror that of ruminal A:P, corroborating the theory of Nozière et al. (2011) that NDF digestibility positively correlates with acetate proportion but negatively correlates with propionate proportion. It should be noted that Benchaar et al. (2006) reported 
no effect of monensin on ERD of grass silage DM and NDF in dairy cows using a Latin square design. The lack of response in the aforementioned study could be due to the pre-exposure of the animals to monensin, which would lower the responses of ruminal microbiota to repeated monensin supplementation (Sauer et al., 1998).

\section{Postprandial Responses of Methane Emissions, VFA Profiles, and In Situ Alfalfa Hay Degradation to Monensin}

This study is the first to show that the postprandial responses to monensin in $\mathrm{CH}_{4}$ emission rates, ruminal VFA profiles, and in situ degradation kinetics declined with both hours after feeding and days of treatment. Consistent with previous studies (Rooke et al., 2014), the hourly $\mathrm{CH}_{4}$ emissions peaked shortly after feeding during the baseline period. Monensin both delayed $\mathrm{CH}_{4}$ production from peaking and reduced the $\mathrm{CH}_{4}$ emission rates after feeding. The degradation of the rapidly degradable fraction of alfalfa NDF was decreased, whereas that of slowly degradable fraction tended to be increased by monensin, suggesting the inhibitory effect of monensin on alfalfa NDF degradation weakened with hours after feeding. Therefore, the $\mathrm{CH}_{4}$-depressing effects of monensin dwindled with time, hours after feeding, and days of treatment, likely because of its stimulatory effect on ruminal propionate proportion and its inhibitory effect on alfalfa NDF degradation weakened with time. The fading of postprandial responses to monensin with hours after feeding was probably due to the passage of monensin from the rumen, whereas the weakening of postprandial responses to monensin with days of treatment probably reflects the development of resistance to monensin by ruminal microbes. Further studies are needed to investigate the adaptive changes of ruminal microbes upon long-term exposure to monensin.

\section{CONCLUSIONS}

Using dairy goats as a model, we showed that monensin decreased $\mathrm{CH}_{4}$ production, ruminal A:P, and fiber digestibility without the confounding effects of DMI and temperature. However, all these effects faded, though at varying rates, during long-term monensin supplementation, suggesting adaptation by developing resistance to monensin by ruminal microbes. The effect of monensin on postprandial $\mathrm{CH}_{4}$ emission rates, ruminal VFA profiles, and in situ degradation kinetics also dwindled with hours after feeding. Despite the adaptation and the small magnitude of $\mathrm{CH}_{4}$ inhibition, monensin can still help mitigate $\mathrm{CH}_{4}$ emissions from ruminants because it can increase propionate production relatively persistently and then decrease the $\mathrm{CH}_{4}$ output per kilogram of milk or meat.

\section{ACKNOWLEDGMENTS}

This research was financially supported by the National Key Research and Development Program of China (award number: 2017YFD0500500). The authors thank F. M. Mitloehner (University of California, Davis) for his technical assistance in operating the environmental control chambers.

\section{REFERENCES}

AOAC International. 2005. Official Methods of Analysis. 18th ed. AOAC Int., Gaithersburg, MD.

Appuhamy, J. A. D. R. N., A. B. Strathe, S. Jayasundara, C. WagnerRiddle, J. Dijkstra, J. France, and E. Kebreab. 2013. Anti-methanogenic effects of monensin in dairy and beef cattle: A metaanalysis. J. Dairy Sci. 96:5161-5173.

Benchaar, C., H. V. Petit, R. Berthiaume, T. D. Whyte, and P. Y. Chouinard. 2006. Effects of addition of essential oils and monensin premix on digestion, ruminal fermentation, milk production, and milk composition in dairy cows. J. Dairy Sci. 89:4352-4364.

Bernier, J. N., M. Undi, J. C. Plaizier, K. M. Wittenberg, G. R. Donohoe, and K. H. Ominski. 2012. Impact of prolonged cold exposure on dry matter intake and enteric methane emissions of beef cows overwintered on low-quality forage diets with and without supplemented wheat and corn dried distillers' grain with solubles. Can. J. Anim. Sci. 92:493-500.

Boadi, D. A., and K. M. Wittenberg. 2002. Methane production from dairy and beef heifers fed forages differing in nutrient density using the sulphur hexafluoride (SF6) tracer gas technique. Can. J. Anim. Sci. 82:201-206.

Brown, D. L., and D. E. Hogue. 1985. Effects of feeding monensin sodium to lactating goats: Milk composition and ruminal volatile fatty acids. J. Dairy Sci. 68:1141-1147.

Chen, M., and M. J. Wolin. 1979. Effect of monensin and lasalocidsodium on the growth of methanogenic and rumen saccharolytic bacteria. Appl. Environ. Microbiol. 38:72-77.

da Fonseca, M. P., A. L. da C. C. Borges, R. R. e Silva, H. F. Lage, A. L. Ferreira, F. C. F. Lopes, C. G. Pancoti, and J. A. S. Rodrigues. 2016. Intake, apparent digestibility, and methane emission in bulls receiving a feed supplement of monensin, virginiamycin, or a combination. Anim. Prod. Sci. 56:1041-1045.

Drackley, J. K. 1999. Biology of dairy cows during the transition period: The final frontier? J. Dairy Sci. 82:2259-2273.

Duffield, T. F., J. K. Merrill, and R. N. Bagg. 2012. Meta-analysis of the effects of monensin in beef cattle on feed efficiency, body weight gain, and dry matter intake. J. Anim. Sci. 90:4583-4592.

Duffield, T. F., A. R. Rabiee, and I. J. Lean. 2008a. A meta-analysis of the impact of monensin in lactating dairy cattle. Part 2. Production effects. J. Dairy Sci. 91:1347-1360.

Duffield, T. F., A. R. Rabiee, and I. J. Lean. 2008b. A meta-analysis of the impact of monensin in lactating dairy cattle. Part 3. Health and reproduction. J. Dairy Sci. 91:2328-2341.

Fairfield, A. M., J. C. Plaizier, T. F. Duffield, M. I. Lindinger, R. Bagg, P. Dick, and B. W. McBride. 2007. Effects of prepartum administration of a monensin controlled release capsule on rumen $\mathrm{pH}$, feed intake, and milk production of transition dairy cows. J. Dairy Sci. 90:937-945.

Gehman, A. M., P. J. Kononoff, C. R. Mullins, and B. N. Janicek. 2008. Evaluation of nitrogen utilization and the effects of monensin in dairy cows fed brown midrib corn silage. J. Dairy Sci. 91:288-300. 
Goopy, J. P., R. Woodgate, A. Donaldson, D. L. Robinson, and R. S. Hegarty. 2011. Validation of a short-term methane measurement using portable static chambers to estimate daily methane production in sheep. Anim. Feed Sci. Technol. 166-167:219-226.

Grainger, C., M. J. Auldist, T. Clarke, K. A. Beauchemin, S. M. McGinn, M. C. Hannah, R. J. Eckard, and L. B. Lowe. 2008. Use of monensin controlled-release capsules to reduce methane emissions and improve milk production of dairy cows offered pasture supplemented with grain. J. Dairy Sci. 91:1159-1165.

Grainger, C., T. Clarke, S. M. McGinn, M. J. Auldist, K. A. Beauchemin, M. C. Hannah, G. C. Waghorn, H. Clark, and R. J. Eckard. 2007. Methane emissions from dairy cows measured using the sulfur hexafluoride $\left(\mathrm{SF}_{6}\right)$ tracer and chamber techniques. J. Dairy Sci. 90:2755-2766.

Guan, H. 2006. Efficacy of ionophores in cattle diets for mitigation of enteric methane. J. Anim. Sci. 84:1896-1906.

Haimoud, D., M. Vernay, C. Bayourthe, and R. Moncoulon. 1995. Avoparcin and monensin effects on the digestion of nutrients in dairy-cows fed a mixed diet. Can. J. Anim. Sci. 75:379-385.

Hegarty, R. S. 1999. Reducing rumen methane emissions through elimination of rumen protozoa. Aust. J. Agric. Res. 50:1321-1328.

Hellwing, A. L. F., P. Lund, M. R. Weisbjerg, M. Brask, and T. Hvelplund. 2012. Technical note: Test of a low-cost and animal-friendly system for measuring methane emissions from dairy cows. J. Dairy Sci. 95:6077-6085.

Hook, S. E., K. S. Northwood, A. D. G. Wright, and B. W. McBride. 2009. Long-term monensin supplementation does not significantly affect the quantity or diversity of methanogens in the rumen of the lactating dairy cow. Appl. Environ. Microbiol. 75:374-380.

Hristov, A. N., J. Oh, C. Lee, and R. Meinen. 2013. Mitigation of greenhouse gas emissions in livestock production: A review of technical options for non- $\mathrm{CO}_{2}$ emissions. FAO Animal Production and Health Paper. No. 177. Food and Agriculture Organization of the United Nations, Rome, Italy.

Janssen, P. H. 2010. Influence of hydrogen on rumen methane formation and fermentation balances through microbial growth kinetics and fermentation thermodynamics. Anim. Feed Sci. Technol. $160: 1-22$.

Jentsch, W., M. Schweigel, F. Weissbach, H. Scholze, W. Pitroff, and M. Derno. 2007. Methane production in cattle calculated by the nutrient composition of the diet. Arch. Anim. Nutr. 61:10-19.

Johnson, K. A., and D. E. Johnson. 1995. Methane emissions from cattle. J. Anim. Sci. 73:2483-2492.

Kadzere, C. T., M. R. Murphy, N. Silanikove, and E. Maltz. 2002. Heat stress in lactating dairy cows: A review. Livest. Prod. Sci. 77:59-91

Kennedy, P. M., and L. P. Milligan. 1978. Effects of cold exposure on digestion, microbial synthesis and nitrogen transformations in sheep. Br. J. Nutr. 39:105-117.

Khorrami, B., A. R. Vakili, M. D. Mesgaran, and F. Klevenhusen. 2015. Thyme and cinnamon essential oils: Potential alternatives for monensin as a rumen modifier in beef production systems. Anim. Feed Sci. Technol. 200:8-16.

Kim, M., M. L. Eastridge, and Z. Yu. 2014a. Investigation of ruminal bacterial diversity in dairy cattle fed supplementary monensin alone and in combination with fat, using pyrosequencing analysis. Can. J. Microbiol. 60:65-71.

Kim, M., T. L. Felix, S. C. Loerch, and Z. Yu. 2014b. Effect of haylage and monensin supplementation on ruminal bacterial communities of feedlot cattle. Curr. Microbiol. 69:169-175.

Lemos, B. J. M., F. G. F. Castro, L. S. Santos, B. P. C. Mendonca, V. R. M. Couto, and J. J. R. Fernandes. 2016. Monensin, virginiamycin, and flavomycin in a no-roughage finishing diet fed to zebu cattle. J. Anim. Sci. 94:4307-4314.

Li, F., Z. Li, S. Li, J. D. Ferguson, Y. Cao, J. Yao, F. Sun, X. Wang, and T. Yang. 2014. Effect of dietary physically effective fiber on ruminal fermentation and the fatty acid profile of milk in dairy goats. J. Dairy Sci. 97:2281-2290.

McGuffey, R. K., L. F. Richardson, and J. I. D. Wilkinson. 2001. Ionophores for dairy cattle: Current status and future outlook. J. Dairy Sci. 84:E194-E203.
Ministry of Agriculture of China. 2004. Feeding standard of meatproducing sheep and goats (NY/Y816-2004). China Agricultural Press, Beijing, China.

Mirzaei-Alamouti, H., S. Moradi, Z. Shahalizadeh, M. Razavian, H Amanlou, T. Harkinezhad, I. Jafari-Anarkooli, C. Deiner, and J. R. Aschenbach. 2016. Both monensin and plant extract alter ruminal fermentation in sheep but only monensin affects the expression of genes involved in acid-base transport of the ruminal epithelium. Anim. Feed Sci. Technol. 219:132-143.

Montano, M. F., O. M. Manriquez, J. Salinas-Chavira, N. Torrentera, and R. A. Zinn. 2015. Effects of monensin and virginiamycin supplementation in finishing diets with distiller dried grains plus solubles on growth performance and digestive function of steers. J. Appl. Anim. Res. 43:417-425.

NRC. 2001. Nutrient Requirements of Dairy Cattle. 7th ed. National Academic Press, Washington, DC.

Newbold, C., R. Wallace, and N. Walker. 1993. The effect of tetronasin and monensin on fermentation, microbial numbers and the development of ionophore-resistant bacteria in the rumen. J. Appl. Bacteriol. 75:129-134.

Nozière, P., F. Glasser, and D. Sauvant. 2011. In vivo production and molar percentages of volatile fatty acids in the rumen: A quantitative review by an empirical approach. Animal 5:403-414.

Odongo, N. E., R. Bagg, G. Vessie, P. Dick, M. M. Or-Rashid, S. E. Hook, J. T. Gray, E. Kebreab, J. France, and B. W. McBride. 2007. Long-term effects of feeding monensin on methane production in lactating dairy cows. J. Dairy Sci. 90:1781-1788.

Offner, A., A. Bach, and D. Sauvant. 2003. Quantitative review of in situ starch degradation in the rumen. Anim. Feed Sci. Technol. 106:81-93.

Ørskov, E., and I. McDonald. 1979. The estimation of protein degradability in the rumen from incubation measurements weighted according to rate of passage. J. Agric. Sci. 92:499-503.

Patra, A., T. Park, M. Kim, and Z. Yu. 2017. Rumen methanogens and mitigation of methane emission by anti-methanogenic compounds and substances. J. Anim. Sci. Biotechnol. 8:13.

Ravva, S. V., C. Z. Sarreal, and R. E. Mandrell. 2013. Altered protozoan and bacterial communities and survival of Escherichia coli O157:H7 in monensin-treated wastewater from a dairy lagoon. PLoS One 8:e54782.

Reveneau, C., S. K. R. Karnati, E. R. Oelker, and J. L. Firkins. 2012. Interaction of unsaturated fat or coconut oil with monensin in lactating dairy cows fed 12 times daily. I. Protozoal abundance, nutrient digestibility, and microbial protein flow to the omasum. J. Dairy Sci. 95:2046-2060.

Rogers, M., J. P. Jouany, P. Thivend, and J. P. Fontenot. 1997. The effects of short-term and long-term monensin supplementation, and its subsequent withdrawal on digestion in sheep. Anim. Feed Sci. Technol. 65:113-127.

Rooke, J. A., R. J. Wallace, C.-A. Duthie, N. McKain, S. M. de Souza, J. J. Hyslop, D. W. Ross, T. Waterhouse, and R. Roehe. 2014 Hydrogen and methane emissions from beef cattle and their rumen microbial community vary with diet, time after feeding and genotype. Br. J. Nutr. 112:398-407.

Russell, J. B. 1987. A proposed mechanism of monensin action in inhibiting ruminal bacterial growth: Effects on ion flux and protonmotive force. J. Anim. Sci. 64:1519-1525.

Russell, J. B. 1998. The importance of $\mathrm{pH}$ in the regulation of ruminal acetate to propionate ratio and methane production in vitro. J. Dairy Sci. 81:3222-3230.

Russell, J. B., and A. J. Houlihan. 2003. Ionophore resistance of ruminal bacteria and its potential impact on human health. FEMS Microbiol. Rev. 27:65-74.

Russell, J. B., and J. L. Rychlik. 2001. Factors that alter rumen microbial ecology. Science 292:1119-1122.

Salles, M. S. V., M. A. Zanetti, E. A. L. Titto, and R. M. C. Conti. 2008. Effect of monensin on performance in growing ruminants reared under different environmental temperatures. Anim. Feed Sci. Technol. 147:279-291.

Sauer, F. D., V. Fellner, R. Kinsman, J. K. Kramer, H. A. Jackson, A. J. Lee, and S. Chen. 1998. Methane output and lactation response 
in Holstein cattle with monensin or unsaturated fat added to the diet. J. Anim. Sci. 76:906-914.

Scharen, M., C. Drong, K. Kiri, S. Riede, M. Gardener, U. Meyer, J. Hummel, T. Urich, G. Breves, and S. Danicke. 2017. Differential effects of monensin and a blend of essential oils on rumen microbiota composition of transition dairy cows. J. Dairy Sci. 100:2765-2783.

Shabat, S. K. B., G. Sasson, A. Doron-Faigenboim, T. Durman, S. Yaacoby, M. E. Berg Miller, B. A. White, N. Shterzer, and I. Mizrahi. 2016. Specific microbiome-dependent mechanisms underlie the energy harvest efficiency of ruminants. ISME J. https://doi .org/10.1038/ismej.2016.62.

Tedeschi, L. O., D. G. Fox, and T. P. Tylutki. 2003. Potential environmental benefits of ionophores in ruminant diets. J. Environ. Qual. 32:1591-1602.

Tomkins, N. W., S. E. Denman, R. Pilajun, M. Wanapat, C. S. McSweeney, and R. Elliott. 2015. Manipulating rumen fermentation and methanogenesis using an essential oil and monensin in beef cattle fed a tropical grass hay. Anim. Feed Sci. Technol. 200:25-34.

Ungerfeld, E. M. 2015. Shifts in metabolic hydrogen sinks in the methanogenesis-inhibited ruminal fermentation: A meta-analysis. Front. Microbiol. 6:37.

Van Soest, P. J., J. B. Robertson, and B. A. Lewis. 1991. Methods for dietary fiber, neutral detergent fiber, and nonstarch polysaccharides in relation to animal nutrition. J. Dairy Sci. 74:3583-3597.
Vendramini, J. M. B., J. M. D. Sanchez, R. F. Cooke, A. D. Aguiar, P. Moriel, W. L. da Silva, O. F. R. Cunha, P. D. S. Ferreira, and A. C. Pereira. 2015. Stocking rate and monensin supplemental level effects on growth performance of beef cattle consuming warm-season grasses. J. Anim. Sci. 93:3682-3689.

von Keyserlingk, G. E., and G. W. Mathison. 1993. The effect of ruminal escape protein and ambient temperature on the efficiency of utilization of metabolizable energy by lambs. J. Anim. Sci. 71:2206-2217.

Waghorn, G. C., H. Clark, V. Taufa, and A. Cavanagh. 2008. Monensin controlled-release capsules for methane mitigation in pasturefed dairy cows. Aust. J. Exp. Agric. 48:65.

Wang, Z. B., H. S. Xin, J. Bao, C. Y. Duan, Y. Chen, and Y. L. Qu. 2015. Effects of hainanmycin or monensin supplementation on ruminal protein metabolism and populations of proteolytic bacteria in Holstein heifers. Anim. Feed Sci. Technol. 201:99-103.

Weissman, C., J. Askanazi, J. Milic-Emili, and J. M. Kinney. 1984. Effect of respiratory apparatus on respiration. J. Appl. Physiol. $57: 475-480$. 